\title{
Sources and transport of dissolved iron and manganese along the continental margin of the Bay of Biscay
}

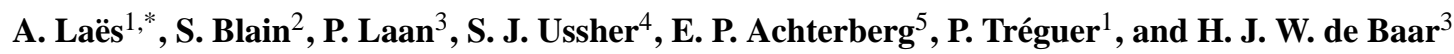 \\ ${ }^{1}$ Institut Universitaire Européen de la Mer, LEMAR UMR CNRS 6539, Place Nicolas Copernic, 29280 Plouzané, France \\ ${ }^{2}$ Centre d'Océanologie de Marseille, LOB UMR CNRS 6535, campus de Luminy, case 901, 13288 Marseille Cedex, France \\ ${ }^{3}$ Royal Netherlands Institute for Sea Research (NIOZ), Texel, The Netherlands \\ ${ }^{4}$ School of Earth, Ocean and Environmental Science, University of Plymouth, PL4 8AA Plymouth, UK \\ ${ }^{5}$ National Oceanography Centre Southampton, University of Southampton, SO14 3ZH Southampton, UK \\ * now at: Ifremer, Département TSI, Centre de Brest, BP 70, 29280 Plouzané, France
}

Received: 29 June 2006 - Published in Biogeosciences Discuss.: 22 September 2006

Revised: 8 January 2007 - Accepted: 22 February 2007 - Published: 14 March 2007

\begin{abstract}
Dissolved iron (DFe; $<0.2 \mu \mathrm{m})$ and dissolved manganese $(\mathrm{DMn} ;<0.2 \mu \mathrm{m})$ concentrations were determined in the water column of the Bay of Biscay (eastern North Atlantic Ocean) in March 2002. The samples were collected along a transect traversing from the European continental shelf over the continental slope. The highest DFe and DMn concentrations $(2.39 \mathrm{nM}$ and $6.10 \mathrm{nM}$, respectively) were observed in the bottom waters on the shelf at stations closest to the coast. The release of trace metal from resuspended particles and the diffusion from pore waters were probably at the origin of elevated DFe and DMn concentrations in the Bottom Boundary Layer (BBL). In the slope region, the highest total dissolvable iron (TDFe), DFe and DMn values $(24.6 \mathrm{nM}, 1.58 \mathrm{nM}$ and $2.12 \mathrm{nM}$, respectively) were observed close to the bottom at depth of ca. 600-700 m. Internal wave activity and slope circulation are thought to be at the origin of this phenomenon. These processes were also very likely the cause of elevated concentrations (DFe: $1.27 \mathrm{nM}, \mathrm{DMn}: 2.34 \mathrm{nM}$ ) measured in surface waters of stations located in the same area. At stations off the continental slope, the vertical distribution of both metals were typical of open ocean conditions, indicating that inputs from the continental margin did not impact the metal distributions in the offshore waters.
\end{abstract}

\section{Introduction}

Trace metals enter the ocean through three different pathways: atmospheric deposition, fluvial discharges and remobilisation from the sediments. The relative importance of the sources is dependent on the nature and source strength of the metal. In the case of iron, which is currently of great

Correspondence to: A. Laës

(agathe.laes@ifremer.fr) interest in marine biogeochemistry, the atmosphere was considered to be the primary source for off shore surface waters. However, there is recent evidence that the flux of iron coming from deep oceanic water (e.g. through upwelling and winter mixing) and derived from local sediment remobilisation on continental shelves, can be of the same order of magnitude, or even larger than atmospheric deposition for oceanic and shelf surface waters (Elrod et al., 2004). In this context, continental margins are of particular interest as intense biogeochemical processes (biological production, sedimentation) take place in these regions. In nearshore areas, the concentrations of manganese and iron are largely determined by riverine inputs and/or interactions with sediments (resuspension or effluxes at the sediment-water interface). This has been demonstrated for several continental margins: Pacific Ocean, near Alaska (Martin et al., 1989), Monterey Bay (Martin and Gordon, 1988), New Zealand (Croot and Hunter, 1998), western (Wu and Luther, 1996) and eastern (Le Gall et al., 1999) North Atlantic Ocean. Moreover, iron and manganese enrichments have also been reported in water masses over the shelf regions of oceanic islands like the Kerguelen plateau (Bucciarelli et al., 2001) and the Galapagos archipelago (Martin et al., 1994; Gordon et al., 1998). Several studies have shown the importance of iron enrichment of seawater, due to interaction with sediment, on the productivity in coastal or oceanic provinces. For the Californian upwelling region, Johnson et al. (1999) and Chase et al. (2005) concluded that the resuspension of particles in the benthic boundary layer followed by upwelling of the iron-rich water sustained a high biological production. Regeneration of iron in sediments has also been demonstrated in regions with suboxic zones including the eastern tropical North Pacific (Landing and Bruland, 1987), the Peru upwelling zone (Bruland et al., 2005) and the Arabian Sea (Witter et al., 2000). In remote high nutrient low chlorophyll (HNLC) regions, lateral transport and subsequent upwelling of iron-rich deep water

Published by Copernicus GmbH on behalf of the European Geosciences Union. 


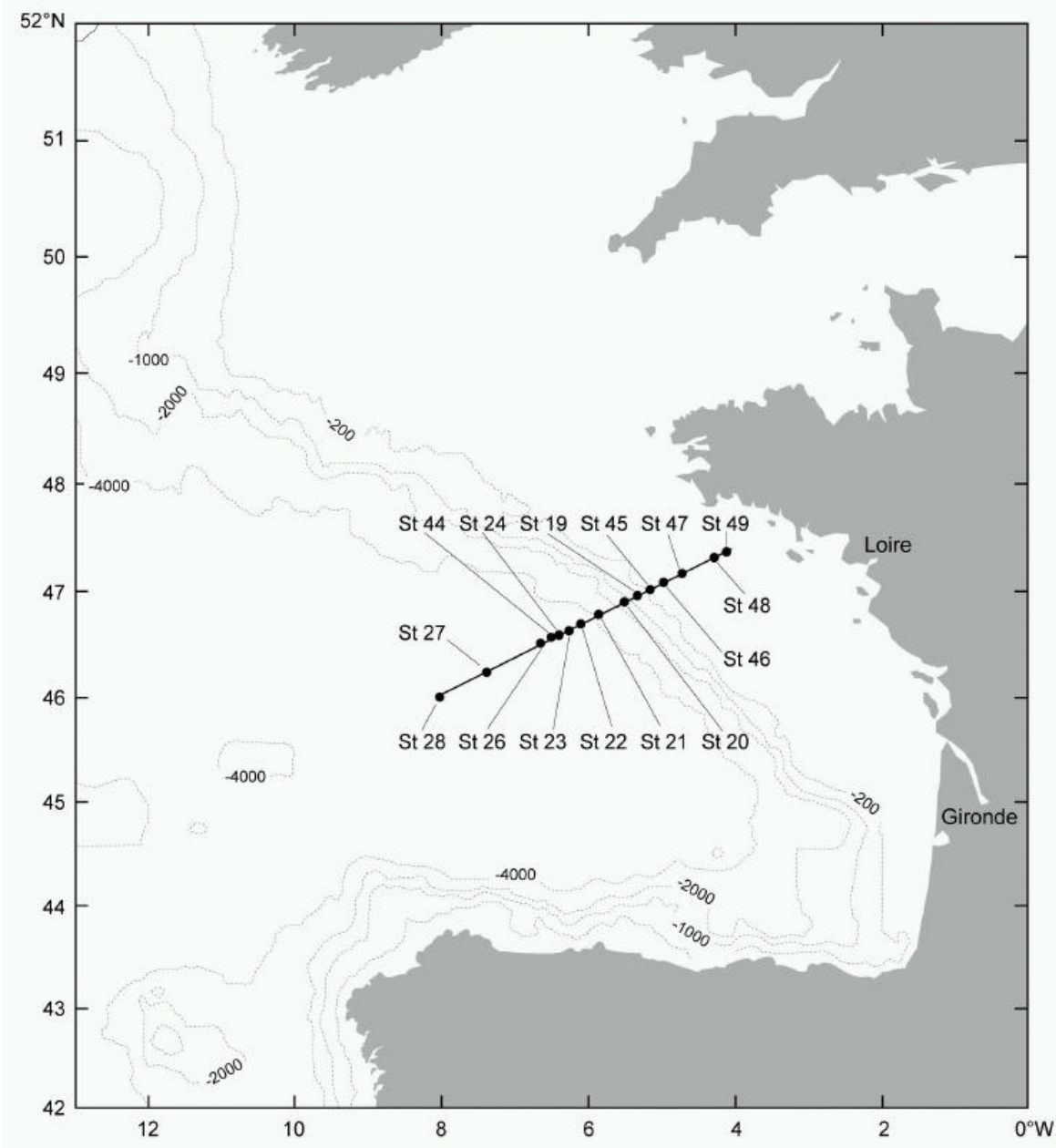

Fig. 1. Sampling location and bathymetry in the Bay of Biscay.

was suggested as the primary source of iron to the surface waters of the Equatorial upwelling zone in the Pacific (Coale et al., 1996; Mackey et al., 2002; Fitzwater et al., 2003) and the Antarctic polar front zone (de Baar et al., 1995; Loscher et al., 1997). Moreover dynamic processes occurring on the continental margins are capable of efficiently moving trace elements from deep to surface waters and to the interior of the ocean (Wells et al., 1999; Lacan and Jeandel, 2001; Mackey et al., 2002; Hoppema et al., 2003). Continental margins, through fluvial inputs, sediment remobilisation and hydrodynamic processes constitute a major source of trace metals for coastal and in some situations also open ocean waters.

We report detailed distributions of dissolved iron (DFe) and dissolved manganese (DMn) along a transect traversing the continental shelf and slope of the eastern North Atlantic Ocean. We also discuss how different hydrodynamic mechanisms that promote resuspension of sediments and transport of particulate and dissolved phases could explain some important features of these two dimensional sections.

\section{Sampling and methods}

Seawater samples were collected during the IRONAGES (Iron Resources and Oceanic Nutrients-Advancement of Global Environment Simulations) cruise (March 2002) on board RV Pelagia, along a transect from the continental shelf in an offshore direction (Fig. 1). Deep water sampling for nutrient and oxygen analyses, was performed using Niskin bottles attached to a rosette CTD frame. Surface water samples were collected using a torpedo fish (see below). Dissolved oxygen was determined using Winkler titrations, and the concentrations of nitrate and phosphate were determined using segmented flow analysis (Grashoff et al., 1983).

Clean seawater was collected using internally Teflon coated samplers (NIOZ) mounted on a Kevlar line. Surface waters ( $3 \mathrm{~m}$ depth) were sampled using a towed torpedo fish and a trace metal clean Teflon bellows pump (Almatec A-15, Germany). For dissolved metal analysis, seawater was filtered using a $0.2 \mu \mathrm{m}$ pore size filter cartridge equipped with a 

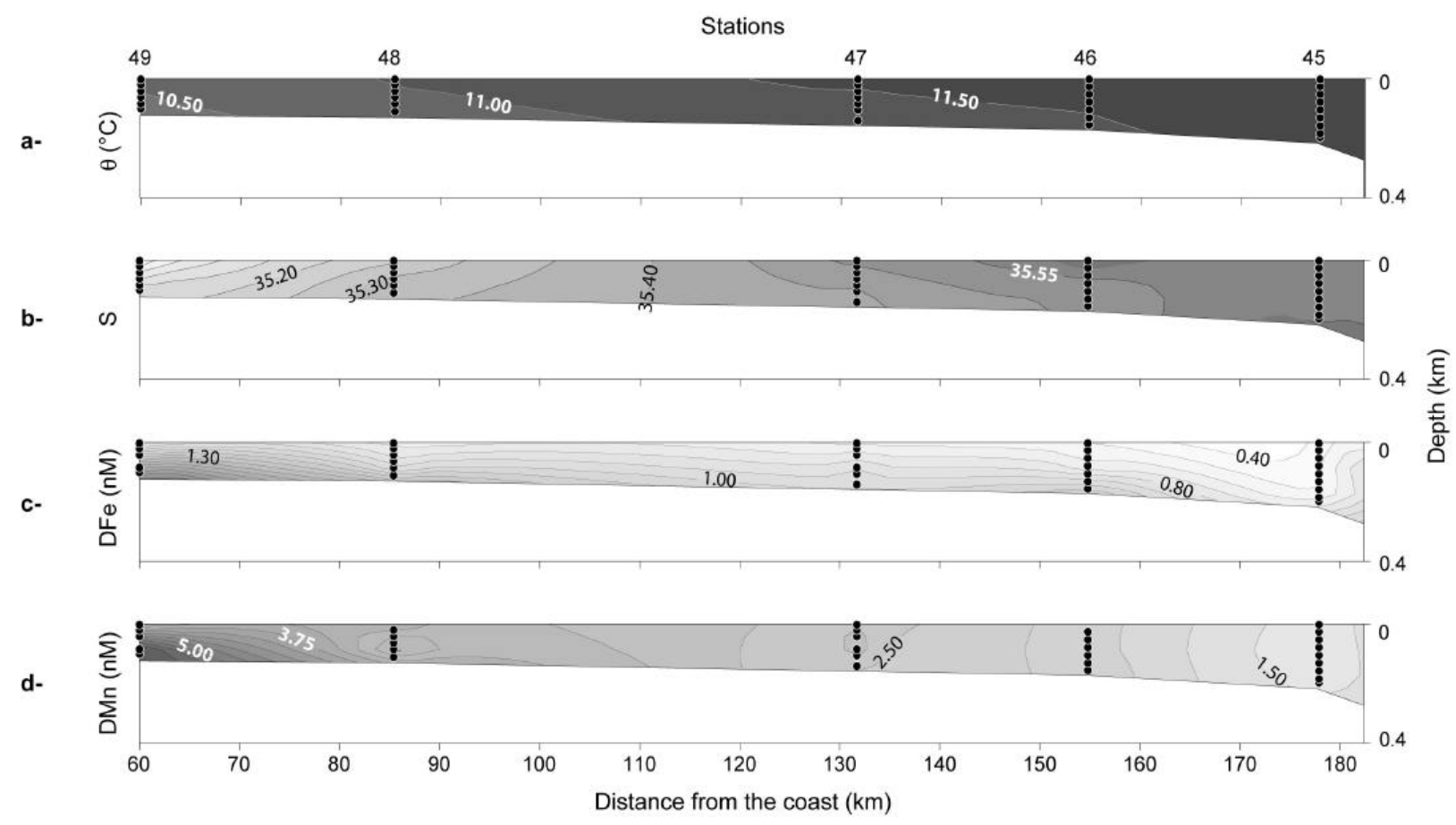

Fig. 2. Two dimensional sections of potential temperature $\Theta($ a), salinity $S(\mathbf{b})$, concentrations of DFe (c) and DMn (d) over the plateau.

$0.45 \mu \mathrm{m}$ prefilter (Sartobran, Sartorius), and acidified to $\mathrm{pH} 2$ (60 $\mu \mathrm{l}$ of $\mathrm{HCl} 30 \%$ Merck, @Ultrapure to $60 \mathrm{ml}$ of water sample) for at least $24 \mathrm{~h}$ prior to analysis. TDFe samples were not filtered but acidified to $\mathrm{pH} 2$ with $60 \mu 1$ of $\mathrm{HCl}(30 \%$ Merck, (BUltrapure) to $60 \mathrm{ml}$ of water sample for at least 6 months prior to analysis. TDFe represents the concentration of dissolved iron plus the most labile fraction of particulate iron (Löscher et al., 1997). Flow Injection Analysis (FIA), with on line preconcentration and chemiluminescence detection, was used for on board measurement of $\mathrm{DFe}$ concentration (Obata et al., 1993). The $\mathrm{pH}$ of the acidified sample was adjusted to 4.5 using ammonia (25\% Merck, ®Ultrapure) and purified ammonium acetate buffer $(2 \mathrm{M})$, before loading onto a 8-hydroxyquinoline preconcentration column (8HQ, resin D, from Dierssen et al., 2001). Calibration curves were obtained using additions of a known amount of dissolved iron to seawater with a DFe concentration below the limit of detection. The mean limit of detection (3 times the standard deviation of 10 blank replicates) was $28 \pm 28 \mathrm{pM}$. The contribution of the FIA manifold to the blank was estimated using different preconcentration times and extrapolation of the signal to a preconcentration time equal to zero. The average blank was $39 \pm 22 \mathrm{pM}(\mathrm{n}=14)$. The contribution of $\mathrm{HCl}$, $\mathrm{NH}_{4} \mathrm{OH}$ and buffer additions to the blank was determined by standard addition of each reagent to low iron seawater. Their contribution to the blank was below the limit of detection. DFe concentrations were corrected for the total blank. TDFe concentrations were determined in laboratory one year after the cruise, using the same instrumentation. Dissolved Mn concentrations were determined in the land-based NIOZ laboratory, using FIA with on line preconcentration and colorimetric detection. The method was based on Mn-catalysed oxidation of tiron by hydrogen peroxide (Mallini and Shiller, 1993). Acidified samples were adjusted to $\mathrm{pH} 7.8-8.2$ by addition of saturated TRIS buffer. The average detection limit and blank were respectively $6.2 \pm 5.5 \mathrm{pM}$ and $25.7 \pm 20.8 \mathrm{pM}$ $(\mathrm{n}=14)$.

\section{Results and discussion}

\subsection{Continental shelf}

\subsubsection{Hydrography}

Physical and chemical properties of the waters at stations 49-45 (shallower than $200 \mathrm{~m}$ ) are reported in the first part of Table 1. At all stations, the highest temperatures $(\Theta)$ were observed in the surface waters. At stations 49 and 48 the highest salinity (S) was observed in the bottom waters, whereas at the other stations small variations of salinity occurred in the water column. Two dimensional sections of $\Theta$ (Fig. 2a) and S (Fig. 2b) show a vertical gradient from station 49 , closest to the coast, to station 45 located at the shelf break. At all depths, $\Theta$ and $\mathrm{S}$ increased in an offshore direction. The strongest vertical gradients of $\sigma_{\theta}$ (potential density) between the surface and the bottom of the water column 
Table 1. Salinity $(\mathrm{S})$, potential temperature $(\Theta)$, concentrations of DMn, DFe and $\mathrm{NO}_{3}^{-}$and potential density $\left(\sigma_{\Theta}\right)$ for stations 49 to 26 .

\begin{tabular}{|c|c|c|c|c|c|c|c|}
\hline & Depth (m) & S & $\theta\left({ }^{\circ} \mathrm{C}\right)$ & $\mathrm{DMn}(\mathrm{nM})$ & $\mathrm{DFe}(\mathrm{nM})$ & $\mathrm{NO}_{3}^{-}(\mu \mathrm{M})$ & $\sigma_{\theta}$ \\
\hline & 3 & 34.95 & 10.84 & 3.13 & 0.73 & 2.7 & 26.77 \\
\hline \multirow[t]{2}{*}{ St 49 (96 m) } & 20 & 35.09 & 10.76 & 3.80 & 1.04 & 4.6 & 26.89 \\
\hline & 40 & 35.16 & 10.76 & 3.88 & 1.17 & 4.6 & 26.95 \\
\hline $47^{\circ} 36^{\prime} 58 \mathrm{~N}$ & 60 & 35.18 & 10.65 & $\mathrm{nd}^{\mathrm{a}}$ & $0.94^{\mathrm{a}}$ & 6.2 & 26.98 \\
\hline \multirow[t]{3}{*}{$04^{\circ} 14^{\prime} 51 \mathrm{~W}$} & 80 & 35.15 & 10.26 & 5.90 & 1.63 & 7.5 & 27.02 \\
\hline & 90 & 35.16 & 10.28 & 6.10 & 2.39 & 7.0 & 27.03 \\
\hline & 3 & 35.23 & 11.03 & $\mathrm{nd}^{\mathrm{c}}$ & 0.69 & 2.1 & 26.95 \\
\hline \multirow[t]{2}{*}{ St $48(105 \mathrm{~m})$} & 20 & 35.25 & 10.95 & 3.60 & 0.68 & 3.7 & 26.98 \\
\hline & 40 & 35.28 & 10.84 & 2.35 & 0.71 & 5.2 & 27.02 \\
\hline $47^{\circ} 29^{\prime} 99 \mathrm{~N}$ & 60 & 35.32 & 10.94 & 2.2 & 0.71 & 5.8 & 27.04 \\
\hline \multirow[t]{3}{*}{$04^{\circ} 30^{\prime} 00 \mathrm{~W}$} & 80 & 35.33 & 10.90 & 2.55 & 0.85 & 6.1 & 27.05 \\
\hline & 100 & 35.33 & 10.81 & 3.90 & 1.52 & 6.4 & 27.07 \\
\hline & 3 & 35.51 & 11.74 & 2.73 & 0.58 & 0.9 & 27.04 \\
\hline \multirow[t]{2}{*}{ St 47 (134 m) } & 20 & 35.51 & 11.62 & 2.46 & 0.71 & 1.5 & 27.06 \\
\hline & 40 & 35.51 & 11.59 & 2.40 & 0.51 & 2.6 & 27.06 \\
\hline $47^{\circ} 16^{\prime} 70 \mathrm{~N}$ & 60 & 35.51 & 11.56 & $\mathrm{nd}^{\mathrm{a}}$ & $0.61^{\mathrm{a}}$ & 4.0 & 27.06 \\
\hline \multirow[t]{4}{*}{$05^{\circ} 14^{\prime} 00 \mathrm{~W}$} & 80 & 35.45 & 11.21 & 2.90 & 0.89 & 5.8 & 27.09 \\
\hline & 100 & 35.44 & 11.16 & 2.17 & 0.89 & 6.0 & 27.09 \\
\hline & 130 & 35.44 & 11.14 & 2.39 & 0.94 & 6.1 & 27.09 \\
\hline & 3 & 35.55 & 11.78 & $\mathrm{nd}^{\mathrm{c}}$ & 0.51 & 4.8 & 27.06 \\
\hline \multirow[t]{2}{*}{ St $46(157 \mathrm{~m})$} & 25 & 35.53 & 11.74 & 2.12 & 0.68 & 3.4 & 27.05 \\
\hline & 50 & 35.53 & 11.73 & 2.15 & 0.44 & 3.8 & 27.05 \\
\hline $47^{\circ} 10^{\prime} 02 \mathrm{~N}$ & 75 & 35.52 & 11.58 & 2.09 & 0.58 & 4.4 & 27.07 \\
\hline \multirow[t]{5}{*}{$05^{\circ} 17^{\prime} 08 \mathrm{~W}$} & 100 & 35.51 & 11.46 & 2.09 & 0.91 & 5.4 & 27.09 \\
\hline & 125 & 35.51 & 11.44 & 2.07 & 1.01 & 5.4 & 27.09 \\
\hline & 150 & 35.51 & 11.42 & 2.22 & 1.17 & 6.1 & 27.10 \\
\hline & 3 & 25.58 & 11.90 & 1.43 & 0.45 & 6.1 & 27.06 \\
\hline & 25 & 35.58 & 11.90 & 1.26 & 0.42 & 6.3 & 27.06 \\
\hline \multirow[t]{2}{*}{ St $45(184 \mathrm{~m})$} & 50 & 35.58 & 11.90 & 1.29 & 0.44 & 6.3 & 27.06 \\
\hline & 75 & 35.58 & 11.89 & 1.41 & 0.46 & 6.4 & 27.06 \\
\hline $47^{\circ} 03^{\prime} 39 \mathrm{~N}$ & 100 & 35.58 & 11.87 & 1.41 & 0.55 & 6.7 & 27.06 \\
\hline \multirow[t]{5}{*}{$05^{\circ} 32^{\prime} 70 \mathrm{~W}$} & 125 & 35.58 & 11.87 & 1.45 & 0.50 & 6.8 & 27.06 \\
\hline & 150 & 35.58 & 11.85 & 1.41 & 0.51 & 7.7 & 27.06 \\
\hline & 175 & 35.57 & 11.71 & 1.33 & 0.54 & 7.9 & 27.09 \\
\hline & 180 & 35.57 & 11.68 & 1.49 & 0.59 & 7.2 & 27.09 \\
\hline & 3 & 35.59 & 11.89 & $\mathrm{nd}^{\mathrm{c}}$ & 0.46 & 5.7 & 27.07 \\
\hline \multirow[t]{2}{*}{ St $19(197 m)$} & 20 & 35.58 & 11.88 & $\mathrm{nd}^{\mathrm{c}}$ & 1.27 & 6.5 & 27.06 \\
\hline & 50 & 35.58 & 11.89 & $\mathrm{nd}^{\mathrm{a}}$ & $0.87^{\mathrm{a}}$ & 8.4 & 27.06 \\
\hline $47^{\circ} 01^{\prime} 79 \mathrm{~N}$ & 100 & 35.57 & 11.75 & $\mathrm{nd}^{\mathrm{a}}$ & $0.98^{\mathrm{a}}$ & 9.1 & 27.08 \\
\hline \multirow[t]{3}{*}{$05^{\circ} 36^{\prime} 49 \mathrm{~W}$} & 125 & 35.57 & 11.65 & $\mathrm{nd}^{\mathrm{a}}$ & $0.94^{\mathrm{a}}$ & 9.4 & 27.10 \\
\hline & 150 & 35.57 & 11.64 & $\mathrm{nd}^{\mathrm{c}}$ & 0.80 & 9.4 & 27.10 \\
\hline & 3 & 35.58 & 11.93 & 1.77 & 0.50 & 5.3 & 25.92 \\
\hline \multirow[t]{2}{*}{ St $20(315 \mathrm{~m})$} & 20 & 35.58 & 11.93 & 1.73 & 0.36 & 7.6 & 27.06 \\
\hline & 40 & 35.59 & 11.93 & 1.79 & 0.89 & 6.3 & 27.06 \\
\hline $47^{\circ} 00^{\prime} 15 \mathrm{~N}$ & 100 & 35.59 & 11.89 & 1.80 & 0.82 & 7.4 & 27.07 \\
\hline \multirow[t]{2}{*}{$05^{\circ} 40^{\prime} 32 \mathrm{~W}$} & 200 & 35.58 & 11.83 & 1.68 & 1.12 & 6.7 & 27.08 \\
\hline & 310 & 35.57 & 11.43 & $\mathrm{nd}^{\mathrm{c}}$ & 1.23 & 6.7 & 27.14 \\
\hline
\end{tabular}

a During a cast, trace metal samples were collected using Teflon coated samplers, nitrate from both Teflon coated samplers and Niskin bottles. If the nitrate concentrations were significantly different, DMn and DFe values were flagged and referenced in Table 1 as "Bottle leaking". Nitrate data presented in Table 1 were obtained from Niskin bottles.

b Contamination during sampling was suspected.

${ }^{\mathrm{c}} \mathrm{DFe}$ values are correct but DMn data set was elevated probably due to contamination during analysis. nd $=$ not determined 
Table 1. Continued.

\begin{tabular}{|c|c|c|c|c|c|c|c|}
\hline & Depth (m) & $\mathrm{S}$ & $\theta\left({ }^{\circ} \mathrm{C}\right)$ & $\mathrm{DMn}(\mathrm{nM})$ & $\mathrm{DFe}(\mathrm{nM})$ & $\mathrm{NO}_{3}^{-}(\mu \mathrm{M})$ & $\sigma_{\theta}$ \\
\hline & 3 & 35.57 & 11.90 & 1.55 & 0.46 & 5.1 & 27.05 \\
\hline \multirow[t]{2}{*}{ St $21(657 \mathrm{~m})$} & 100 & 35.58 & 11.85 & $\mathrm{nd}^{\mathrm{c}}$ & 1.03 & 6.4 & 27.07 \\
\hline & 200 & 35.55 & 11.60 & $\mathrm{nd}^{\mathrm{c}}$ & 1.17 & 7.2 & 27.10 \\
\hline $46^{\circ} 59^{\prime} 42 \mathrm{~N}$ & 300 & 35.57 & 11.51 & 1.28 & 1.17 & 8.6 & 27.12 \\
\hline \multirow[t]{3}{*}{$05^{\circ} 41^{\prime} 92 \mathrm{~W}$} & 400 & 35.57 & 11.22 & 1.15 & 1.18 & 10.6 & 27.18 \\
\hline & 500 & 35.57 & 11.06 & 1.24 & 1.54 & 11.0 & 27.21 \\
\hline & 3 & 35.59 & 11.96 & 1.2 & 0.46 & 5.1 & 27.06 \\
\hline \multirow[t]{2}{*}{ St 22 (794 m) } & 50 & 35.58 & 11.95 & $\mathrm{nd}^{\mathrm{c}}$ & 1.19 & 6.0 & 27.05 \\
\hline & 200 & 35.57 & 11.65 & $\mathrm{nd}^{\mathrm{c}}$ & 1.23 & 9.1 & 27.10 \\
\hline $46^{\circ} 59^{\prime} 31 \mathrm{~N}$ & 400 & 35.55 & 11.12 & $\mathrm{nd}^{\mathrm{c}}$ & 1.21 & 12.8 & 27.18 \\
\hline \multirow[t]{4}{*}{$05^{\circ} 42^{\prime} 30 \mathrm{~W}$} & 600 & 35.60 & 10.42 & nd $^{\mathrm{a}}$ & $2.00^{\mathrm{a}}$ & 13.7 & 27.34 \\
\hline & 700 & 35.63 & 10.22 & $\mathrm{nd}^{\mathrm{c}}$ & 1.58 & 15.6 & 27.41 \\
\hline & 3 & 35.57 & 11.87 & 2.34 & 0.63 & 5.5 & 27.05 \\
\hline & 50 & 35.57 & 11.88 & $\mathrm{nd}^{\mathrm{c}}$ & 1.06 & 6.3 & 27.06 \\
\hline \multirow[t]{2}{*}{ St 23 (1014 m) } & 100 & 35.58 & 11.88 & 2.01 & 0.66 & 6.5 & 27.06 \\
\hline & 200 & 35.56 & 11.63 & 2.11 & 0.80 & 7.7 & 27.10 \\
\hline $46^{\circ} 57^{\prime} 78 \mathrm{~N}$ & 300 & 35.56 & 11.47 & 1.16 & 0.78 & 10.5 & 27.13 \\
\hline \multirow[t]{7}{*}{$05^{\circ} 45^{\prime} 87 \mathrm{~W}$} & 500 & 35.57 & 10.92 & $\mathrm{nd}^{\mathrm{b}}$ & $2.09^{b}$ & 14.5 & 27.23 \\
\hline & 600 & 35.58 & 10.45 & 2.12 & 1.20 & 16.1 & 27.33 \\
\hline & 700 & 35.69 & 10.22 & 1.97 & 1.46 & 16.5 & 27.45 \\
\hline & 800 & 35.75 & 10.14 & 1.00 & 1.27 & 17.0 & 27.51 \\
\hline & 900 & 35.72 & 9.74 & 0.69 & 1.43 & 16.9 & 27.56 \\
\hline & 3 & 35.59 & 12.15 & 1.47 & 0.60 & 5.7 & 27.02 \\
\hline & 25 & 35.59 & 12.14 & 1.26 & 0.73 & 5.4 & 27.02 \\
\hline \multirow[t]{2}{*}{ St $24(2057 \mathrm{~m})$} & 200 & 35.59 & 11.88 & 1.20 & 0.65 & 6.9 & 27.07 \\
\hline & 400 & 35.56 & 11.28 & 0.62 & 1.26 & 11.8 & 27.16 \\
\hline $46^{\circ} 56^{\prime} 03 \mathrm{~N}$ & 600 & 35.56 & 10.58 & 0.62 & 1.23 & 16.0 & 27.29 \\
\hline \multirow[t]{11}{*}{$05^{\circ} 49^{\prime} 90 \mathrm{~W}$} & 850 & 35.73 & 10.28 & 0.41 & 1.39 & 16.9 & 27.48 \\
\hline & 1000 & 35.74 & 9.61 & 0.78 & 1.50 & 17.4 & 27.60 \\
\hline & 1200 & 35.67 & 8.77 & 0.52 & 1.29 & 17.9 & 27.68 \\
\hline & 1400 & 35.50 & 7.40 & 0.42 & 1.19 & 18.7 & 27.75 \\
\hline & 1800 & 35.15 & 4.81 & 0.70 & 1.06 & 19.6 & 27.82 \\
\hline & 3 & 35.58 & 11.95 & 1.46 & 0.34 & 6.1 & 27.09 \\
\hline & 200 & 35.56 & 11.65 & 1.30 & 0.54 & 6.8 & 27.09 \\
\hline & 500 & 35.56 & 10.92 & $\mathrm{nd}^{\mathrm{a}}$ & $0.68^{\mathrm{a}}$ & 13.3 & 27.23 \\
\hline & 800 & 35.71 & 10.26 & 0.40 & 0.81 & 16.9 & 27.46 \\
\hline & 900 & 35.78 & 10.06 & 0.38 & 0.83 & 17.0 & 27.55 \\
\hline & 1000 & 35.76 & 9.64 & 0.38 & 0.78 & 17.3 & 27.61 \\
\hline \multirow[t]{2}{*}{ St $44(2967 \mathrm{~m})$} & 1100 & 35.74 & 9.21 & 0.36 & 0.76 & 18. & 27.66 \\
\hline & 1200 & 35.67 & 8.62 & 0.36 & 0.79 & 17.7 & 27.71 \\
\hline $46^{\circ} 54^{\prime} 26 \mathrm{~N}$ & 1500 & 35.24 & 5.73 & 0.37 & 0.66 & 18.6 & 27.78 \\
\hline \multirow[t]{13}{*}{$05^{\circ} 54^{\prime} 08 \mathrm{~W}$} & 1600 & 35.20 & 5.31 & 0.47 & 0.78 & 19.1 & 27.80 \\
\hline & 1700 & 35.12 & 4.65 & 0.38 & 0.83 & 19.5 & 27.81 \\
\hline & 1800 & 35.08 & 4.32 & 0.46 & 0.73 & 19.5 & 27.82 \\
\hline & 1900 & 35.06 & 4.17 & $\mathrm{nd}^{\mathrm{c}}$ & 0.72 & 19.9 & 27.82 \\
\hline & 2000 & 35.06 & 3.99 & 0.45 & 0.78 & 20.1 & 27.83 \\
\hline & 2200 & 35.01 & 3.46 & 0.51 & 0.77 & 20.8 & 27.85 \\
\hline & 2300 & 34.99 & 3.24 & 0.48 & 0.75 & 21.1 & 27.86 \\
\hline & 2750 & 34.95 & 2.68 & 0.53 & 0.80 & 22.0 & 27.87 \\
\hline & 2800 & 34.94 & 2.59 & 0.52 & 0.77 & 22.1 & 27.88 \\
\hline & 3 & 35.58 & 12.24 & 1.35 & 0.40 & 4.5 & 27.00 \\
\hline & 50 & 35.58 & 12.24 & $\mathrm{nd}^{\mathrm{b}}$ & $0.84^{b}$ & 4.4 & 27.00 \\
\hline & 250 & 35.58 & 11.84 & 1.19 & 0.64 & 6.6 & 27.07 \\
\hline & 450 & 35.56 & 11.19 & 0.47 & 0.92 & 12.1 & 27.18 \\
\hline
\end{tabular}


Table 1. Continued.

\begin{tabular}{llllllll}
\hline & Depth $(\mathrm{m})$ & $\mathrm{S}$ & $\theta\left({ }^{\circ} \mathrm{C}\right)$ & $\mathrm{DMn}(\mathrm{nM})$ & $\mathrm{DFe}(\mathrm{nM})$ & $\mathrm{NO}_{3}^{-}(\mu \mathrm{M})$ & $\sigma_{\theta}$ \\
\hline & 650 & 35.58 & 10.56 & $\mathrm{nd}^{\mathrm{b}}$ & $1.69^{\mathrm{b}}$ & 15.5 & 27.31 \\
$\mathrm{St} \mathrm{26}(4100 \mathrm{~m})$ & 900 & 35.77 & 10.13 & $\mathrm{nd}^{\mathrm{c}}$ & 1.11 & 16.6 & 37.53 \\
& 1060 & 35.76 & 9.38 & 0.34 & 1.07 & 17.2 & 27.65 \\
$46^{\circ} 51^{\prime} 94 \mathrm{~N}$ & 1270 & 35.65 & 8.42 & 0.39 & 1.00 & 17.8 & 27.72 \\
$05^{\circ} 59^{\prime} 50 \mathrm{~W}$ & 1480 & 35.34 & 6.26 & 0.37 & 0.84 & 18.5 & 27.78 \\
& 1900 & 35.02 & 3.90 & $\mathrm{nd}^{\mathrm{c}}$ & 0.83 & 19.0 & 27.81 \\
& 2020 & 35.02 & 3.79 & 0.33 & 1.32 & 19.2 & 27.83 \\
& 2220 & 35.01 & 3.49 & 0.47 & 1.08 & 20.1 & 27.85 \\
& 2625 & 34.97 & 2.89 & 0.47 & 0.93 & 20.8 & 27.87 \\
& 3030 & 34.94 & 2.55 & 0.50 & 0.89 & 21.5 & 27.88 \\
& 3360 & 34.93 & 2.37 & 0.53 & 0.88 & 22.4 & 27.88 \\
& 3570 & 34.92 & 2.29 & 0.49 & 0.89 & 22.4 & 27.88 \\
& 3780 & 34.91 & 2.23 & 0.56 & 0.88 & 22.7 & 27.89 \\
\hline
\end{tabular}

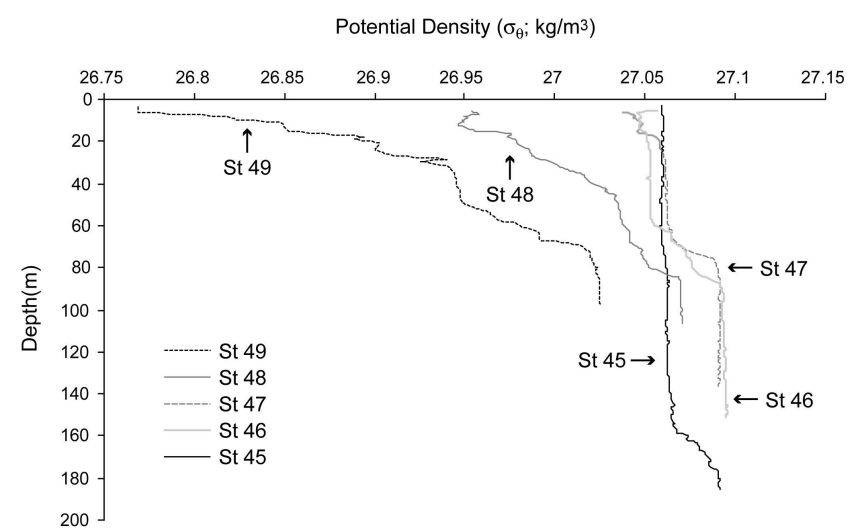

Fig. 3. Potential density $\left(\sigma_{\Theta}, \mathrm{kg} / \mathrm{m}^{3}\right)$ profiles for $\mathrm{St} 49,48,47,46$, and 45 .

were observed at St 49 and 48 (Fig. 3). Both stations were well stratified in the first $20 \mathrm{~m}$ of the water column. Furthermore, the surface mixed layer (SML) for stations 46 and 45 was deep, at 60 and $160 \mathrm{~m}$, respectively. At all stations, a bottom boundary layer (BBL) with a constant $\sigma_{\theta}$ was observed. The thickness of the BBL increased gradually from station $49(12 \mathrm{~m})$ to station $46(59 \mathrm{~m})$ and then decreased pronouncedly to $12 \mathrm{~m}$ at station 45 . The variations in $\mathrm{S}$ and $\Theta$ in this region can largely be explained by the mixing of coastal and offshore seawaters. This is demonstrated by the linear relationship between $\mathrm{S}$ and $\Theta$ (Fig. 4). However, there is a deviation from the straight mixing line corresponding to surface waters at stations $49(3 \mathrm{~m}, 20 \mathrm{~m}, 40 \mathrm{~m}$ depths $)$ and 48 (3 $\mathrm{m}$ depth). Castaing et al. (1999) reported similar anomalies over the plateau of the Biscay Bay. In winter, they identified shallow layers of surface waters with low salinity and temperature as a result of freshwater inputs from the Loire and the Gironde estuaries. Our observations of surface wa-

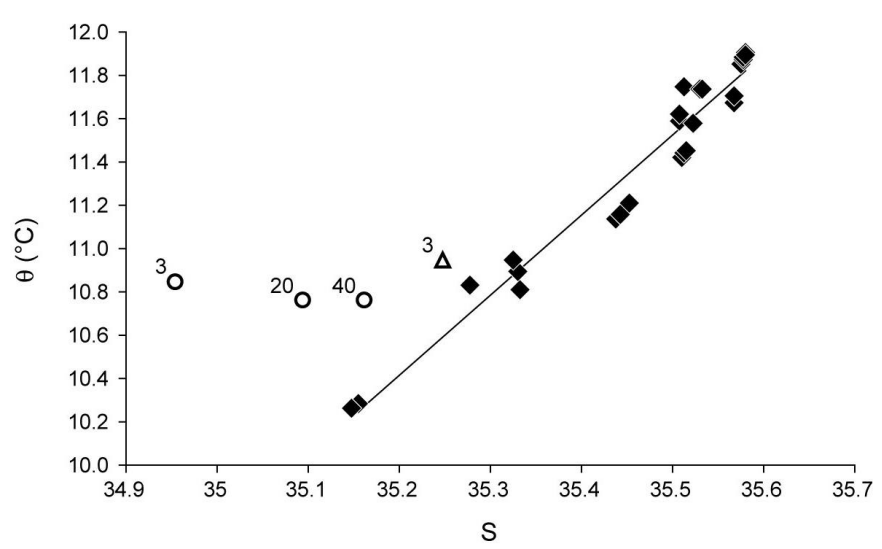

Fig. 4. Salinity-potential temperature $(\Theta-S)$ diagram for the plateau $\left(\Theta=3.72 \mathrm{~S}-120.58, \mathrm{R}^{2}=0.96\right.$, standard deviation of slope 0.16 , standard deviation of intercept: 0.10 , opened triangle: $3 \mathrm{~m}$ for $\mathrm{St}$ 48, opened circles: 3, 20 and $40 \mathrm{~m}$ for St 49).

ters with a low density at stations 49 and 48 (Fig. 3) agree with these observations. We observed higher surface waters temperatures for these waters as a result of a relatively rapid warming during spring due to direct solar heating. This feature will result in a more pronounced stratification of the surface waters, as also reported by Castaing et al. (1999) for a cruise in May.

An important feature of the hydrography in the shelf region is the presence of the BBL. The constancy in the density values shows well mixed bottom waters (Fig. 3). In our case, tidal currents causing friction over the bottom floor and generating mixing were most likely the major drivers of the BBL formation. From stations 49 to 46, the thickness of BBL was limited by a strong pycnocline located around $80 \mathrm{~m}$, therefore the thickest BBL was observed at the deepest stations. For station 45 close to the shelf break, other processes of 
mixing occurred (see below) which limited the formation of the BBL.

\subsubsection{DFe and DMn distributions}

The concentrations of DFe and DMn decreased from the coast in an offshore direction (Figs. 2c and d). The highest concentrations of DFe $(2.39 \mathrm{nM})$ and DMn $(6.10 \mathrm{nM})$ were observed in the bottom waters of station 49 (Table 1). The lowest concentrations of DFe and DMn, $0.45 \mathrm{nM}$ and $1.43 \mathrm{nM}$, respectively, were observed in the surface waters of station 45. At all stations, concentrations of DFe increased with depth, indicating a benthic source. Two different types of vertical DMn distributions were observed. At station 48, a minimum of DMn was observed at intermediate depths. Whereas at stations 47 to 45 , the vertical distributions of DMn were quite uniform, indicating that the distribution of this element at these stations was determined by mixing, with a weaker benthic source strength compared with $\mathrm{Fe}$.

The enhanced concentrations of DMn and DFe in the bottom waters indicate the role of sediments as a source of $\mathrm{Fe}$ and $\mathrm{Mn}$, with probably resuspension in the BBL acting to transfer these elements to the water column. Figure 5 illustrates the variations of DFe and DMn concentrations and turbidity for station 49 . The highest DFe and DMn concentrations coincided with maximum turbidity in the bottom waters probably as a result of desorption from resuspended particulate matter. In fact, the metal enrichment was most pronounced in the bottom waters of stations 49 and 48, which were located in the "Grande Vasière" region (Jouanneau et al., 1999). This mid-shelf mud belt is mainly composed of silty clayey sediments, which are readily resuspended and typically have a shallow oxygenated zone. Thouzeau et al. (2007) ${ }^{1}$ identified a sediment resuspension up to 50 $60 \mathrm{~m}$ off the bottom in the "Grande Vasière" location over a tidal cycle. This could explain the significant inputs of DFe and DMn into the BBL probably via desorption from the resuspended particles. Stations 45,46 and 47 are located outside the "Grande Vasiere". This area is mainly composed of coarse-grained sandy sediments which are well oxygenated (Jouanneau et al., 1999). This type of sediment is not readily resuspended and likely to form a weaker source of DFe and DMn than the "Grande Vasière" sediments. In addition, the BBL at stations 46 and 45 is thicker than at stations 48 and 49, and hence inputs of DFe and DMn from resuspended particles were possibly more strongly diluted.

The release of DMn and DFe through pore water diffusion into the bottom waters, possibly aided by turbulent mixing of the bottom waters of the BBL, may play an important role in the Bay of Biscay. The importance of internal

\footnotetext{
${ }^{1}$ Thouzeau, G., Le Loc'h, F., Lunven, M., Lazure, P., AndrieuxLoyer, F., Philippon, X., and Richard, M.: Vertical export of particulate matter on the continental shelf of the Bay of Biscay (NE Atlantic): spatial and seasonal patterns, Progress in Oceanography, submitted, 2007.
}

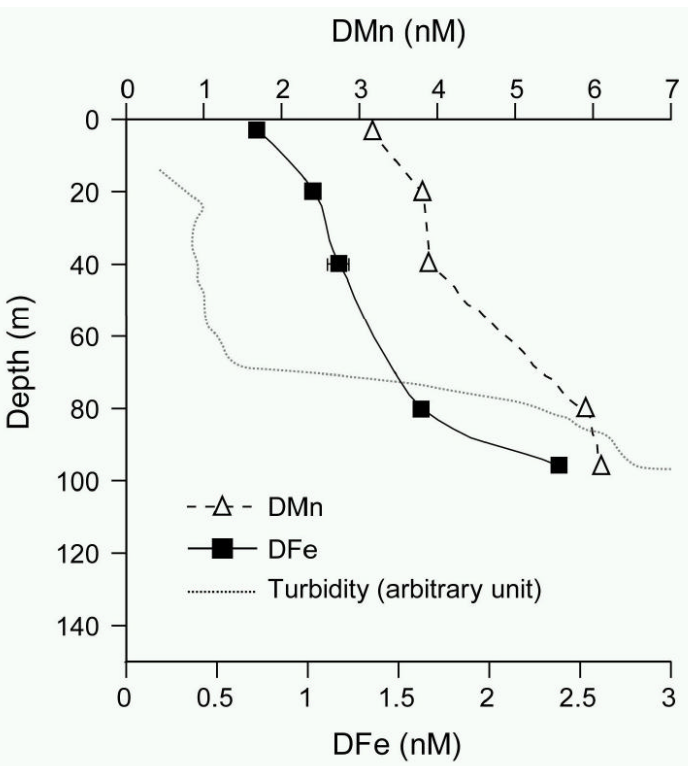

Fig. 5. DFe (black squares), DMn (opened triangles) and turbidity vertical profiles for station 49.

cycling of $\mathrm{Fe}$ and $\mathrm{Mn}$ depends on the redox conditions in the sediment and the overlying water and, thus, is usually closely linked to the quality and quantity of the organic matter deposited on the sediment (organic content \% wt, Slomp et al., 1997). In undisturbed sediments, oxygen is reduced near the sediment - water interface, followed by the reduction of nitrate, manganese oxides, iron oxides, sulfate, and carbon dioxide. In steady-state conditions, all of the dissolved $\mathrm{Mn}^{2+}$ and $\mathrm{Fe}^{2+}$ produced due to $\mathrm{Mn}$ and $\mathrm{Fe}$ oxide reduction are reoxidized in the surface sediment (thick $\mathrm{O}_{2}$ penetration depth). Practically no dissolved metal escape to the overlying water. However, in sediments disturbed by bioturbation or other physical disturbances, an increase in the reducing conditions and a shoaling of the oxygen penetration depth is generally happening (Morforld et al., 1995). In fact sediment particles located at or above the $\mathrm{O}_{2}$ penetration depth commonly accumulate manganese and iron oxides (Anschuzt et al., 2000). Dissolved reduced forms of manganese and iron may then diffuse towards the sediment water interface (Kristiantsen et al., 2002; Van der Zee et al., 2002). Sorbed $\mathrm{Fe}^{2+}$ and solid phase $\mathrm{Fe}(\mathrm{II})$ may also be transported back into the oxidized layer through sediment mixing and subsequently re-oxidize and precipitate as Fe(III) oxyhydroxide. Precipitation of $\mathrm{Mn}^{2+}$ as reduced authigenic minerals may also take place. The sediments at shallow stations (depth around $100 \mathrm{~m}$ ) in this studied region are strongly bioturbated (Jouanneau et al., 1989; Lesueur and Tastet, 1994), with organic carbon contents $>2 \%$ (Hyacinthe et al., 2001). In such sediments, enhanced porewater DMn and DFe concentrations are likely to be produced by the decomposition of the organic matter with associated oxygen consumption and metal oxide reduction. 


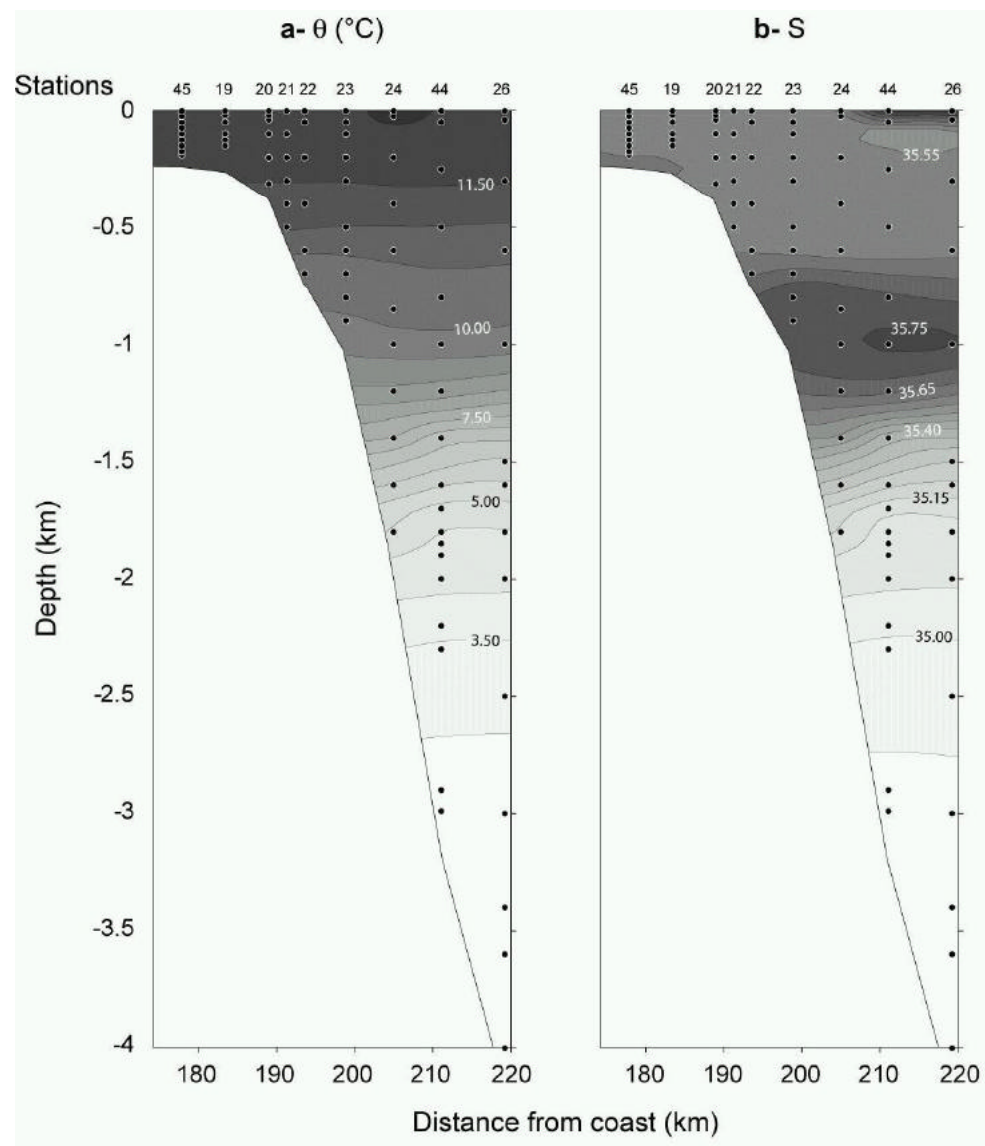

Fig. 6. Two dimensional distributions of potential temperature $\Theta($ a) and salinity $S$ (b) over the slope.

We do not have quantitative estimates of the porewater DFe and DMn concentrations or fluxes for our study area. However it was reported that $\mathrm{Fe}$ and Mn pore water concentrations ( 0 and $5 \mathrm{~cm}$ in the sediments of the Aquitaine margin, $150 \mathrm{~m}$ depth) were in the range $0-100 \mu \mathrm{M}$ (Chaillou et al., 2003 and Hyacinthe et al., 2001). In Van der Zee et al. (2001) and Van der Zee et al. (2002), Fe and Mn pore water concentrations for stations over the Iberian continental margin (104 and $223 \mathrm{~m}$ depth), were in the range $0-70$ and $0-400 \mu \mathrm{M}$, respectively. The oxygen concentrations in the bottom water, the oxygen penetration depth and the organic content of the sediments for the two areas are similar: Aquitaine margin ( 230 and $235 \mu \mathrm{M}, 5$ and $6 \mathrm{~mm}, 2$ and $2.32 \% \mathrm{wt}$ ), Iberian continental margin (209-235 $\mu \mathrm{M}, 1$ and $7.5 \mathrm{~mm}, 0.33-4,58 \%$ wt). We can then hypothesize that the manganese upward flux was close to the one obtained in the Iberian continental margin: 0.1 to $13.3 \mu \mathrm{molm}^{-2} \mathrm{day}^{-1}$. This is comparable to the $\mathrm{Mn}$ and Fe fluxes of 9.76 and $5.18 \mu \mathrm{molm}^{-2}$ day $^{-1}$, respectively, reported by Berelson et al. (2003) at a $100 \mathrm{~m}$ depth station. Benthic Fe and Mn fluxes in the Bay of Biscay are likely to be of similar magnitude to fluxes for the Iberian continental margin and the California continental margin. Desorption of $\mathrm{Fe}$ and $\mathrm{Mn}$ from the particulate forms resus- pended from the sediments as well as release from the pore waters were probably the main sources of metals to the bottom waters over the plateau.

\subsection{The continental slope}

\subsubsection{Hydrography}

Section plots of $\Theta, S$, and concentrations of DFe, DMn, and $\mathrm{NO}_{3}^{-}$over the continental slope region are summarised in the second and third part of Table 1 and are presented in Fig. 6. Surface waters $\left(\Theta=11.95^{\circ} \mathrm{C}, \mathrm{S}=35.58\right)$ on the continental slope comprised eastern North Atlantic Central Water (ENACW, $\Theta=11.23^{\circ} \mathrm{C}, \mathrm{S}=35.57$ ), formed in the eastern North Atlantic by deep winter time convection (Van Aken, 2001). Enhanced salinities at depth between 700 and $1100 \mathrm{~m}$ (Fig. 6b, $\Theta=9.54^{\circ} \mathrm{C}, \mathrm{S}=35.74$ ) were the result of mixing between the Mediterranean Outflow Water (MOW) and the ENACW (Van Aken, 2000). The deepest water mass at stations 44 and $26,\left(\Theta=2.84^{\circ} \mathrm{C}, \mathrm{S}=34.96\right)$ was the North Atlantic Deep Water (NADW, McCave et al., 2001). 


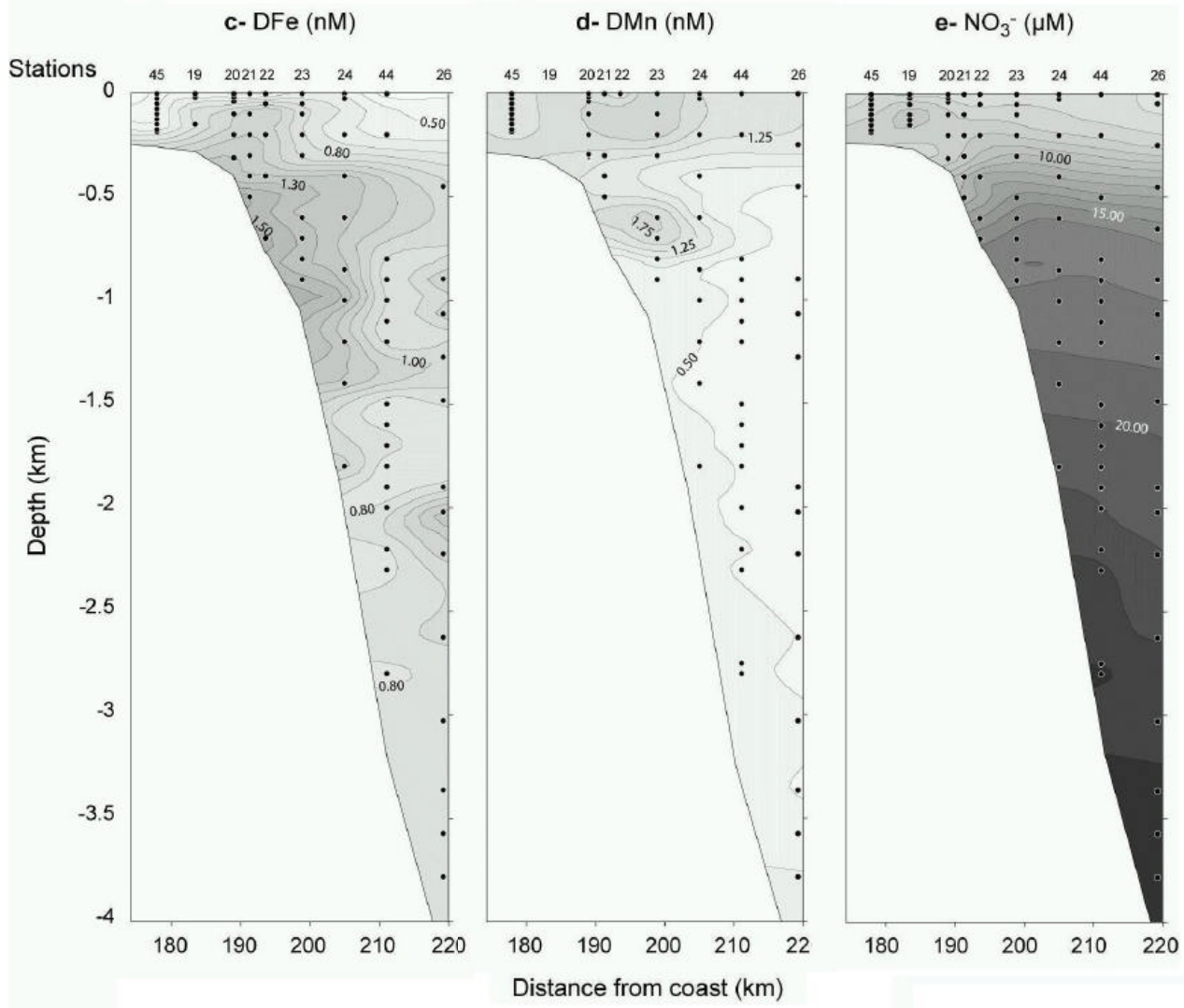

Fig. 6. Continued. Two dimensional distributions of concentrations of $\mathrm{DFe}(\mathbf{c}), \mathrm{DMn}(\mathbf{d})$, and $\mathrm{NO}_{3}^{-}$(e) over the slope.

\subsubsection{Distributions of DFe and DMn}

The highest concentration of DFe $(1.58 \mathrm{nM})$ was observed in bottom waters $(700 \mathrm{~m})$ of station 22 (Fig. 6c). In the region between stations 20 to 24, horizontal gradients of DFe were observed at all depths, with the highest concentrations of DFe in the bottom waters. In the top $250 \mathrm{~m}$ of the water column, the concentrations of DFe ranged between 0.46 to $1.23 \mathrm{nM}$, with the highest DFe concentrations observed at stations 21 and 22 located near the shelf-break. Below $2000 \mathrm{~m}$, concentrations of DFe were relatively constant $(0.89 \pm 0.16 \mathrm{nM})$. The distribution of DMn (Fig. 6d) indicates two different areas with enhanced concentrations. The first area was located in the surface water above $200 \mathrm{~m}$ for stations 20 and 23. The second area was located at a depth of around $600 \mathrm{~m}$ with a maximum concentration of DMn $(2.12 \mathrm{nM})$ at station 23. Below $1000 \mathrm{~m}$, the gradient of the DMn versus depth was weak. DMn concentrations reached $0.49 \pm 0.06 \mathrm{nM}$ below $2000 \mathrm{~m}$, and a small DMn increase was observed in the bottom waters. The distribution of $\mathrm{NO}_{3}^{-}$(Fig. 6e) was mainly dominated by vertical gradients which were most pronounced between 250 and $1000 \mathrm{~m}$. Horizontal gradients were only present in the vicinity of the shelf break (stations 19 to 22).
Similarly to the shelf region, sediments appeared to be a major source for the enhanced metal concentrations observed in bottom waters, probably through pore water diffusion. However, diagenetic processes on their own can not explain the pronounced horizontal gradient observed over a distance of nearly $20 \mathrm{~km}$ between station 20 and station 44. The Bay of Biscay is a highly dynamic region, with the presence of amongst the largest internal tidal waves in the world (Baines, 1982; Serpette and Mazé, 1989; Pingree and New, 1995). The internal waves are caused by the interaction between the incoming oceanic tidal waves and the shelf break. The wave amplitude is maximum at the slope, and can be enhanced by storms, which are a frequent phenomenon in the eastern North Atlantic Ocean (Le Tareau and Mazé, 1993; Huthnance, 1995). Such hydrodynamic processes at the shelf edge have been widely described (Cacchione and Southard, 1974; Cacchione and Drake, 1986; New, 1988; Huthnance, 1995; De Silva et al., 1997; Wollast and Chou, 2001; Gerkema et al., 2004; Lam et al., 2004) and modelled (Ribbe and Holloway, 2001; Gerkema et al., 2004; Lam et al., 2004). Indeed, several studies have shown that internal tide and its shoaling can generate local resuspension of sediments: over the Mediterranean margin (Puig et al., 2001), the California margin (Cacchione et al., 2002; McPhee-Shaw et al., 2004), 


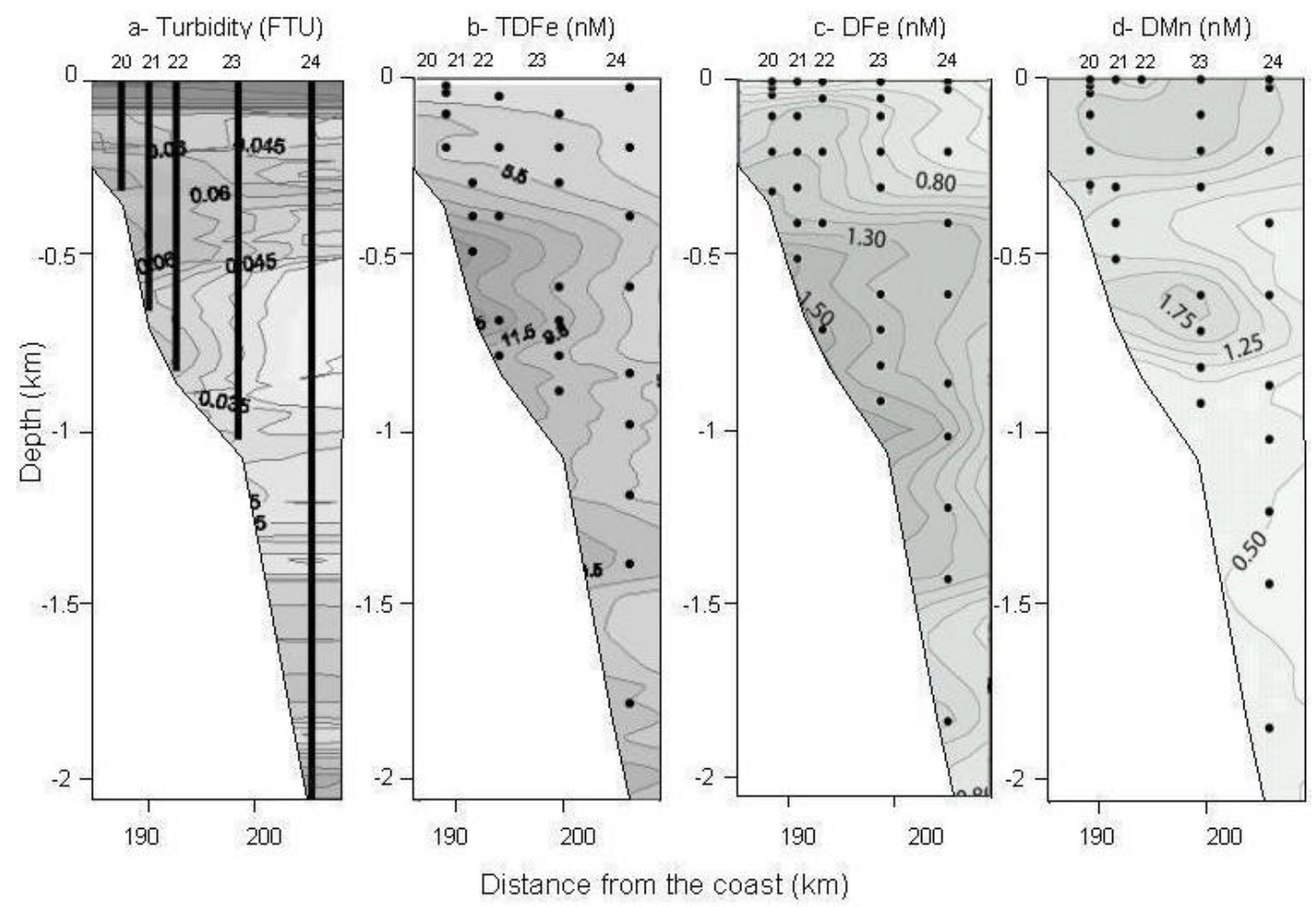

Fig. 7. Two dimensional distributions of turbidity (a), concentrations of TDFe (b), DFe (c) and DMn (d) for a part of the slope.

the Porcupine Bank (Dickson and McCave, 1986; Thorpe and White, 1988), the Celtic continental margin (Heathershaw and Codd, 1985; Heathershaw et al., 1987), and the Faeroe-Shetland Channel (Hosegood et al., 2004).

In the Bay of Biscay, New and Pingree (1990) recorded internal displacements of amplitude up to $150 \mathrm{~m}$ and energy dissipation of $8 \mathrm{kJm}^{-2}$, and confirmed that internal tide and wave currents are strong enough to make important contribution to nearbed mixing. Futhermore, $33 \mathrm{~m}$ off the bottom in a water depth of $548 \mathrm{~m}$, at a station located $47^{\circ} 28 \mathrm{~N}$ and $06^{\circ} 38 \mathrm{~W}$, Pingree and Le Cann (1989) recorded a maximum instantaneous downslope current of $95 \mathrm{~cm} / \mathrm{s}$ and attributed it to internal tide actions. Moreover ADCP measurements at $47^{\circ} 01 \mathrm{~N}, 06^{\circ} 08 \mathrm{~W}$ during September 1992 confirmed maximum current strength above the slope between 400 and $600 \mathrm{~m}$ depth (B. Le Cann, personal communication). The presence of intense nepheloid layers most likely caused by internal waves has been reported at depths between 500 and $2250 \mathrm{~m}$ along the European margin (Dickson and McCave, 1986; Durrieu De Madron et al., 1999; McCave et al., 2001). Internal wave breaking could hence explain the enhanced DMn and DFe concentrations observed in this depth range in the water column of the slope region, mobilising these metals from the sediments (Figs. $6 \mathrm{c}$ and d). Figure 7 shows the two dimensional distributions of turbidity, TDFe, DFe and DMn for a narrow portion of the slope (St 20, 21, $22,23,24)$. TDFe and DFe distributions show strong simi- larity, with the highest concentrations close to the seafloor of stations 21 and 22 (TDFe: St 21: $20.89 \mathrm{nM}(-500 \mathrm{~m})$ and St 22: $24.60 \mathrm{nM}(-700 \mathrm{~m})$. DFe: St 21: $1.54 \mathrm{nM}(-500 \mathrm{~m})$ and St 22: $1.58 \mathrm{nM}(-700 \mathrm{~m}))$. The turbidity profile also shows strong values for the bottom of the stations 19, 20 and 22 $(0.079,0.065,0.064$ FTU respectively) indicating the presence of nepheloid layers. This confirms an input of both the dissolved and particulate forms of iron from the sediments. Lower concentrations in surface waters of stations 22 and 24 are observed (TDFe: $1.97 \mathrm{nM}(-50 \mathrm{~m}), 1.90 \mathrm{nM}(-200 \mathrm{~m})$; DFe: $0.46 \mathrm{nM}(-3 \mathrm{~m})$ and $0.60 \mathrm{nM}(-3 \mathrm{~m}))$. They are related to the highest turbidity values obtained for the surface waters (St 22: $0.118(-20 \mathrm{~m})$; St 24: $0.103(-10 \mathrm{~m})$ ). This suggests the presence of an algal bloom. Further analysis is needed to confirm this hypothesis. Nitrate concentrations between 400 and $700 \mathrm{~m}$ at stations 22 and 23 did not show perturbed distribution (Fig. 6e). In Hyacinthe et al. (2001), pore water concentrations were $1 \mu \mathrm{molL}^{-1}$ for nitrate, $30 \mu \mathrm{molL}^{-1}$ for $\mathrm{Fe}^{2+}$ and $8 \mu \mathrm{molL}^{-1}$ for $\mathrm{Mn}^{2+}$ (Bay of Biscay, $1000 \mathrm{~m}$ depth, $-5 \mathrm{~cm}$ below the sediment surface). If we consider similar pore water concentrations for our studied area, the ratio concentration in water column/ concentration in the pore waters, were 0.12, 20000 and 5000, for nitrate, DFe and DMn respectively. It is obvious that particulate resuspension and mixing of pore waters with deep waters, resulting from internal wave breaking, can strongly affect DMn and DFe concentrations, but with little effect on nitrate distributions. 
Huthnance (1995) highlighted slope circulation as an additional important dynamic process over the continental margin. The north western European slope current flows polewards along the continental margin with a speed intensity varying between 100 and $300 \mathrm{~cm} \mathrm{~s}^{-1}$ (Huthnance, 1995, Wollast and Chou, 2001). Durrieu De Madron et al. (1999) and Thorpe and White (1988) indicated slope circulation and seasonal eddy activity to be important dynamic mechanisms that control the entrainment and the dispersion of the suspended particulate matter from the neritic domain to the deep ocean. This would signify that slope circulation could also be at the origin of the metal advection along the slope and towards the open ocean. The influence of internal waves is also likely to be important for the mixing and upward flux of Fe to the surface waters, and hence to primary production (Pingree et al,. 1986; New, 1988; New and Pingree, 1990; Pingree and New, 1995). These hydrodynamic processes may therefore form an important supply for new DFe in conjunction with other major nutrients when depleted in surface, and sustain phytoplankton blooms, as observed by Lampert et al. (2002) in spring 1998 and Thouzeau et al. (2007) ${ }^{1}$ in March 2002.

The depth profiles of DFe and DMn for station 44 are typical for deep oceanic profiles (Fig. 8), showing a nutrienttype and scavenged behaviour for DFe and DMn, respectively. The concentrations of DFe in the surface water were in good agreement with values reported in the eastern North Atlantic offshore of Portugal (Blain et al., 2004), but slightly lower than DFe concentrations reported by $\mathrm{Wu}$ and Luther III (1994) in the North West Atlantic. The concentrations of $\mathrm{DFe}$ in deep waters are typical for the North Atlantic (Wu et al., 2001). The concentrations of DMn were also in the range reported in the literature for surface and deep waters of the Atlantic Ocean (Statham and Burton, 1986; Statham et al., 1998; Landing et al., 1995). Therefore, at station 44, no clear impact of the continental slope or shelf was observed for DFe and DMn. This indicates that the enhanced DFe and DMn concentrations observed at different places over the continental shelf and slope did not propagate offshore as far as station 44. One of the reasons why we did not observe a more pronounced influence of the shelf sediments on the abundance of trace metals in the surface waters off-shore was because benthic metals fluxes at that time of year are probably relatively low. It could also be caused by low intensity and short term advective transport at this period of the study. This confirms that the long distance transport of DFe away from its source is only possible when specific conditions are met, such as strong advection and low scavenging as reported by Laës et al. (2003).

\section{Conclusions}

The continental margin of the Bay of Biscay showed enhanced DFe and DMn concentrations in the bottom waters of the shelf and slope regions. The processes contributing

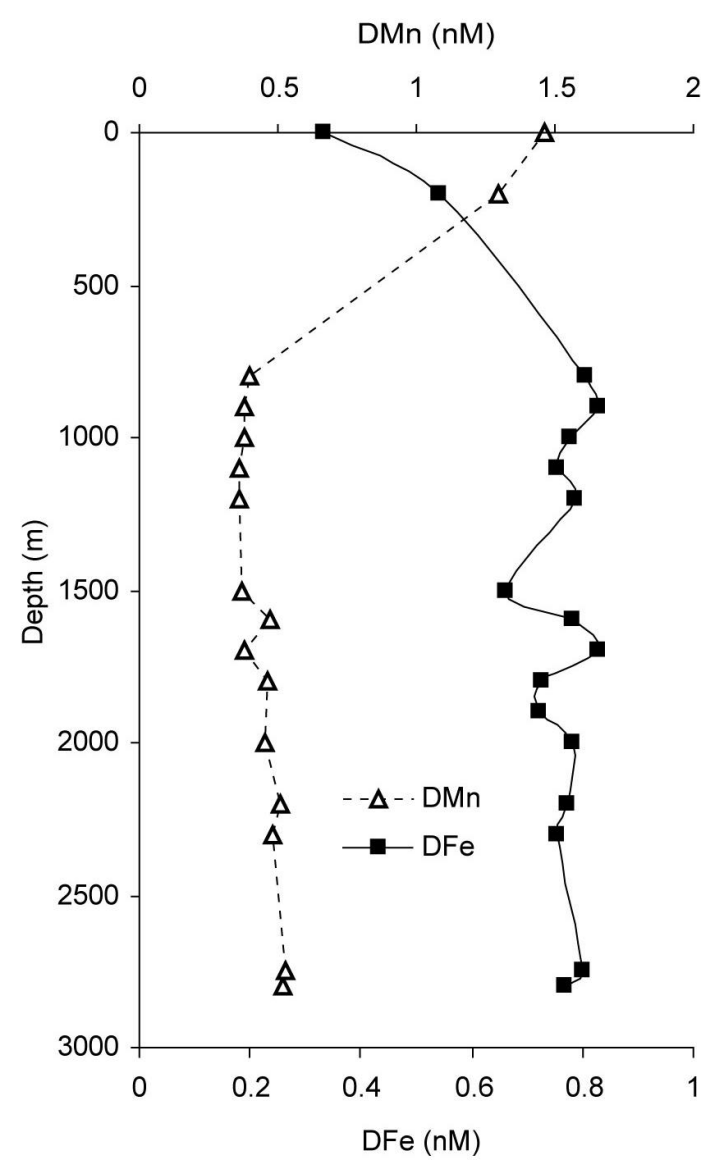

Fig. 8. Vertical profiles for St 44 for DFe (black squares) and DMn (opened triangles).

to the enhanced metal concentrations in the region include: mixing with coastal waters, resuspension of sediment and direct release from pore waters.

Internal wave shoaling and slope circulation appear to form important hydrodynamic processes which intensified the trace metal enrichment of the water column and also transported the metal-rich water to the surface waters. The influence of continental margin on the distribution of trace metals for this particular period of the year seems to be confined to this region. Long distance transfer of the metals into the open ocean was not observed. During our cruise, real-time data on the intensity and magnitude of the physical forces (internal wave breaking, along slope current, hydrological processes inducing resuspension) were not collected. Moreover the iron and manganese fluxes coming from the sediment were not measured. This has hampered quantitative discussion on the relative importance of the different sources and processes. As highlighted by McPhee-Shaw (2006) there is a need for a physical oceanography coupled to biogeochemistry study to bring to light the dynamics causing dispersal of bottom boundary layer fluid into interior waters in order to quantify lateral transport of dissolved and particulate 
chemical constituents and to better understand feedbacks between supply of benthic iron and primary productivity on continental shelves. Our paper brings forward some hypothesis in the understanding of trace metal enrichment in the vicinity of a continental slope. Quantitative estimates will require further investigations concerning the sediment composition, the intensity of diagenesis and of resuspension processes, the nature of transport and the mixing of water masses.

Acknowledgements. The captain and the crew of the RV Pelagia are gratefully acknowledged. We also would like to thank E. van Weerlee for nutrient and oxygen determination, M. Briand and R. Marc for their work on the illustrations, and B. Le Cann for helpful discussion on hydrodynamic processes. Contribution $\mathrm{N}^{\circ}$ 1011 of the IUEM, European Institute for Marine Studies (Brest, France). Funding by the IRONAGES project (EVK2-1999-00031) is also acknowledged.

Edited by: T. W. Lyons

\section{References}

Anschutz, P., Sundby, B., Lefrançois, L., Luther III, G. W., and Mucci, A.: Interactions between metal oxides and species of nitrogen and iodine in bioturbated marine sediments, Geochim. Cosmochim. Acta, 64(16), 2751-2763, 2000.

Baines, P. G.: On internal tide generation models, Deep-Sea Res., 29, 307-338, 1982.

Berelson, W., Mcmanus, J., Coale, K. H., Johnson, K. S., Burdige, D., Kilgore, T., Colodner, D., Chavez, F., Kudela, R., and Boucher, J.: A time series of benthic flux measurements from Monterey Bay, CA., Cont. Shelf Res., 23, 454-481, 2003.

Blain, S., Guieu, C., Claustre, H., Leblanc, K., Moutin, T., Quéguiner, B., and Sarthou, G.: Availability of iron and major nutrients for phytoplankton in the north-east Atlantic Ocean, Limnol. Oceanogr., 49(6), 2095-2104, 2004.

Bruland, K. W., Rue, E. L., Smith, G. J., and DiTullio, G. R.: Iron, macronutrients and diatom blooms in the Peru upwelling regime: brown and blue waters of Peru, Mar. Chem., 93, 81-103, 2005.

Bucciarelli, E., Blain, S., and Tréguer, P.: Iron and manganese in the wake of the Kerguelen Islands (Southern Ocean), Mar. Chem. 73, 21-36, 2001.

Cacchione, D. A. and Drake, D. E.: Nepheloid layers and internal waves over continental shelves and slope, Geo-Mar. Lett., 6, 147-152, 1986.

Cacchione, D. A., Pratson, L. F., and Ogston, A. S: The shaping of continental slopes by internal tides, Science, 296, 724-727, 2002.

Cacchione, D. A. and Southard, J. B.: Incipient sediment movement by shoaling internal gravity waves, J. Geophys. Res., 79, 22372242, 1974.

Castaing, P., Froidefond, J. M., Lazure, P., Weber, O., Prud'homme, R., and Jouanneau, J. M.: Relationship between hydrology and seasonal distribution of suspended sediments on the continental shelf of the Bay of Biscay, Deep-Sea Res. Part II, 46, 1979-2001, 1999.
Chaillou, G., Schäfer, J., Anschutz, P., Lavaux, G., and Blanc, G.: The behaviour of arsenic in muddy sediments of the Bay of Biscay (France), Geochim. Cosmochim. Acta, 67(16), 2993-3003, doi:10.1016/S0016-7037(03)00204-7, 2003.

Chase, Z., Johnson, K. S., Elrod, V. A., Plant, J. N., Fitzwater, S. E., Pickell, L., and Sakamoto, C. M.: Manganese and iron distributions off central California influenced by upwelling and shelf width, Mar. Chem., 95, 235-254, 2005.

Coale, K. H., Fitzwater, S. E., Gordon, R. M., Johnson, K. S., and Barber, R. T.: Control of community growth and export production by upwelled iron in the equatorial Pacific Ocean, Nature, 379, 621-624, 1996.

Croot, P. L. and Hunter, K. A.: Trace metal distributions across the continental shelf near Otago Peninsula, New Zealand, Mar. Chem., 62, 185-201, 1998.

de Baar, H. J. W., De Jong, J. T. M., Bakker, D. C. E., Löscher, B. M., Veth, C., Bathmann, U., and Smetacek, V.: Importance of iron for plankton blooms and carbon dioxide drawdown in the Southern Ocean, Nature, 373, 412-415, 1995.

De Silva, I. P. D., Imberger, J., and Ivey, G. N.: A breaking internal wave ray at a sloping bottom, J. Fluid Mech., 350, 1-27, 1997.

Dickson, R. R. and McCave, I. N.: Nepheloid layers on the continental slope west of Porcupine Bank, Deep-Sea Res. Part A, 33, 791-818, 1986.

Dierssen, H., Balzer, W., and Landing W. M.: Simplified synthesis of an 8-hydroxyquinoline chelating resin and a study of trace metal profiles from Jellyfish Lake, Palau, Mar. Chem. 73, 173192, 2001.

Durrieu De Madron, X., Castaing, P., Nyffeler, F., and Courp, T.: Slope transport of suspended particulate matter on the Aquitaine margin of the Bay of Biscay, Deep-Sea Res. Part II 46, 2003 2027, 1999.

Elrod, V. A., Berelson, W. M., Coale, K. H., and Johnson, K. S.: The flux of iron from continental shelf sediments: a missing source for global budgets, Geophys. Res. Lett., 31, L12307, doi:10.1029/2004JL020216, 2004.

Fitzwater, S. E., Johnson, K. S., Elrod, V. A., Ryan, J.P., Coletti, L.J., Tanner, S. J., Gordon, R. M., and Chavez, F. P.: Iron, nutrient and phytoplankton biomass relationships in upwelled waters of the California coastal system, Cont. Shelf Res., 23, 15231544, 2003.

Gerkema, T., Lam, F. P., and Maas, L. R. M.: Internal tides in the Bay of Biscay: conversion rates and seasonal effects, Deep-Sea Res. Part II, 51, 2995-3008, 2004.

Gordon, R. M., Johnson, K. S., and Coale, K. H.: The behaviour of iron and other trace elements during the IronEx-1 and PlumEx experiments in the Equatorial Pacific, Deep-Sea Res., 45, 9951041, 1998.

Grashoff, K., Erhardt, M., and Kremling, K.: Methods in Seawater Analyses, Wiley-VCH, Weinheim, 632, 1983.

Heathershaw, A. D. and Codd, J. M.: Sandwaves, internal waves and sediment mobility at the shelf-edge in the Celtic Sea, Oceanol. Acta, 8, 391-401, 1985.

Heathershaw, A. D., New, A. L., and Edwards, P. D.: Internal tides and sediment transport at the shelf break in the Celtic Sea, Cont. Shelf Res., 7, 485-517, 1987.

Hoppema, M., de Baar, H. J. W., Fahrbach, E., Hellmer, H. H., and Klein, B.: Substantial advective iron loss diminishes phytoplankton production in the Antartic Zone, Global Biogeochem. Cycles, 
17(1), 1-9, 1025, doi:10.1029/2002GB001957, 2003.

Hosegood, P., Bonnin, J., and van Haren, H.: Solibore-induced sediment resuspension in the Faeroe-Shetland Channel, Geophys. Res. Lett., 31, L09301, doi:10.1029/2004GL019544, 2004.

Huthnance, J. M.: Circulation, exchange and water masses at the ocean margin: the role of physical processes at the shelf edge, Prog. Oceanogr., 35, 353-431, 1995.

Hyacinthe, C., Anschutz, P., Carbonel, P., Jouanneau, J. M., and Jorissen, F. J.: Early diagenetic processes in the muddy sediments of the Bay of Biscay, Mar. Geol., 177, 111-128, 2001.

Johnson, K. S., Chavez, F. P., and Friederich, G. E.: Continentalshelf sediment as a primary source of iron for coastal phytoplankton, Nature, 398, 697-700, 1999.

Jouanneau, J. M., Weber, O., Latouche, C., Vernet, J. P., and Dominik, J.: Erosion, non-deposition and sedimentary processes through a sedimentological and radioisotopic study of surficial deposits from the "Ouest-Gironde vasiere" (Bay of Biscay), Cont. Shelf Res., 9, 325-342, 1989.

Jouanneau, J. M., Weber, O., Cremer, M., and Castaing, P.: Finegrained sediment budget on the continental margin of the Bay of Biscay, Deep-Sea Res. Part II, 46, 2205-2220, 1999.

Kristiansen, K. D., Kristensen, E., and Jensen M. H.: The influence of water column hypoxia on the behaviour of manganese and iron in sandy coastal marine sediment, Est. Coast. Shelf Sci., 55, 645-654, doi:10.1006/ecss.2001.0934, 2002.

Lacan, F. and Jeandel, C.: Tracing Papua New Guinea imprint on the central Equatorial Pacific Ocean using neodymium isotopic compositions and Rare Earth Element patterns, Earth Planet. Sci. Lett., 5779, 1-16, 2001.

Laës, A., Blain, S., Laan, P., Achterberg, E. P., Sarthou, G., and De Baar, H. J. W.: Deep dissolved iron profiles in the eastern North Atlantic in relation to water masses, Geophys. Res. Lett., 30(17), 1-3, doi:10.1029:2003GL017902, 2003.

Lam, F. P. A., Maas, L. R. M., and Gerkema, T.: Spatial structure of tidal and residual currents as observed over the shelf break in the Bay of Biscay, Deep-Sea Res., Part I 51, 1075-1096, 2004.

Lampert, L., Quéguiner, B., Labasque, T., Pichon, A., and Lebreton, N.: Spatial variability of phytoplankton composition and biomass on the eastern continental shelf of the Bay of Biscay (north-east Atlantic Ocean). Evidence for a bloom of Emiliania huxleyi (Prymnesiophyceae) in spring 1998, Cont. Shelf Res., 22, 1225-1247, 2002.

Landing W. M. and Bruland, K. W.: The contrasting biogeochemistry of iron and manganese in the Pacific Ocean, Geochim. Cosmochim. Acta, 51, 29-43, 1987.

Landing, W. M., Cutter, G. A., Dalziel, J. A., Flegal, A. R., Powell, R. T., Schmidt, D., Shiller, A., Statham, P., Westerlund, S., and Resing, J.: Analytical intercomparaison results from the 1990 Intergovernmental Oceanographic Commision open-ocean baseline survey for trace metals : Atlantic Ocean, Mar. Chem., 49, 253-265, 1995

Le Gall, A. C., Staham, P. J., Morley, N. H., Hydes, D. J., and Hunt, C. H.: Processes influencing distributions and concentrations of $\mathrm{Cd}, \mathrm{Cu}, \mathrm{Mn}$ and $\mathrm{Ni}$ at the North West European shelf break, Mar. Chem., 68, 97-115, 1999.

Le Tareau, J. Y. and Mazé, R.: Storms effects on the baroclinic tidal field in the Bay of Biscay, J. Mar. Syst., 4, 327-347, 1993.

Lesueur, P. and Tastet, J. P.: Facies, internal structures and sequences of modern Gironde-derived muds on the Aquitaine inner shelf, France, Mar. Geol., 120, 267-290, 1994.

Loscher, B. M., De Baar, H. J. W., De Jong, J. T. M., Veth, C., and Dehairs, F.: The distribution of Fe in the Antarctic Circumpolar Current, Deep-Sea Res. Part II, 44, 143-187, 1997.

Mackey, D.J., O'sullivan, J. E., and Watson, R. J.: Iron in the western Pacific : a riverine or hydrothermal source for iron in the Equatorial undercurrent? Deep-Sea Res. Part I, 49, 877-893, 2002.

Mallini, L. J. and Shiller, A. M.: Determination of dissolved manganese in seawater by flow injection analysis with colorimetric detection, Limnol. Oceanogr., 38, 1290-1295, 1993.

Martin, J. H., Coale, K. H., Johnson, K. S., Fitzwater, S. E., Gordon, R. M., Tanner, S. J., Hunter, C. N., Elrod, V. A., Nowiicki, J. L., Coley, T. L., Barber, R. T., Lindley, S., Watson, A. J., Van Scoy, K., Law, C. S., Liddicoat, M.I., Ling, R., Stanton, T., Stockel, J., Collins, C., Anderson, A., Bidigare, R., Ondrusek, M., Latasa, M., Millero, F.J., Lee, K., Yao, W., Zhang, J. Z., Friederich, G., Sakamoto, C., Chavez, F., Buck, K., Kolber, Z., Greene, R., Falkowski, P., Chisholm, S. W., Hoge, F., Swift, R., Yungel, J., Turner, S., Nightingale, P., Hatton, A., Liss, P., and Tindale, N. W.: Testing the iron hypothesis in ecosystems of the equatorial Pacific Ocean, Nature 371, 123-129, 1994.

Martin, J. H. and Gordon, R. M.: Northeast Pacific iron distributions in relation to phytoplankton productivity, Deep-Sea Res., 35, 177-196, 1988.

Martin, J. H., Gordon, R. M., Fitzwater, S. E., and Broenkow, W. W.: VERTEX: phytoplankton/iron studies in the Gulf of Alaska, Deep-Sea Res., 36, 649-680, 1989.

McCave, I. N., Hall, I. R., Antia, A. N., Chou, L., Dehairs, F., Lampitt, R. S., Thomsen, L., Van Weering, T. C. E., and Wollast, R.: Distribution, composition and flux of particulate material over the European margin at $47^{\circ}-50^{\circ} \mathrm{N}$, Deep-Sea Res. Part II, 48, 3107-3139, 2001

McPhee-Shaw, E.: Boundary-interior exchange: Reviewing the idea that internal-wave mixing enhances lateral dispersal near continental margins. Deep-Sea Res. Part II, 53, 42-59, 2001.

McPhee-Shaw, E. E, Sternberg, R. W., Mullenbach, B., and Ogston, A. S.: Observations of intermediate nepheloid layers on the northern California continental margin, Cont. Shelf Res., 24, 693-720, 2004.

Morford, J. L., Emerson, S. R., Breckel, E. J., and Kim, S. H.: Diagenesis of oxyanions (V, U, Re, and Mo) in pore waters and sediments from a continental margin, Geochim. Cosmochim. Acta, 69(21), 5021-5032, doi:10.1016/j.gca.2005.05.015, 2005.

New, A. L.: Internal tidal mixing in the Bay of Biscay, Deep-Sea Res., 35, 691-709, 1988.

New, A. L. and Pingree R. D.: Large-amplitude internal soliton packets in the central Bay of Biscay, Deep-Sea Res, 37, 513$524,1990$.

Obata, H., Karatani, H., and Nakayama, E.: Automated determination of iron in seawater by chelating resin concentration and chemiluminescence detection, Anal. Chem., 65, 1524-1528, 1993.

Pingree, R. D., Mardell, G. T., and New, A. L.: Propagation of internal tides from upper slopes of the Bay of Biscay, Nature 321, 154-158, 1986.

Pingree, R. D. and Le Cann, B.: Celtic and Armorican slope and shelf residual currents, Progress in Oceanography 23, 303-338, 1989. 
Pingree, R. D. and New, A. L.: Structure, seasonal development and sunlight spatial coherence of the internal tide on the Celtic and Armorican shelves and in the Bay of Biscay, Deep Sea Res. Part I, 42, 245-284, 1995.

Puig, P., Palanques, A., and Guillén, J.: Near-bottom suspended sediment variability caused by storms and near-inertial internal waves on the Ebro mid continental shelf (NW Mediterranean), Mar. Geol., 178, 81-93, 2001.

Ribbe, J. and Holloway, P. E.: A model of suspended sediment transport by internal waves, Cont. Shelf Res., 21, 395-422, 2001.

Serpette, A. and Mazé, R.: Internal tides in the Bay of Biscay, Cont. Shelf Res., 9, 795-821, 1989.

Slomp, C. P., Malschaert, J. F. P., Lohse, L., and van Raaphorst, W.: Iron and manganese cycling in different sedimentary environments on the North Sea continental margin, Cont. Shelf Res., 179, 1083-1117, 1997.

Statham, P.J., Yeats, P.A., Landing, W.M.: Manganese in the eastern Atlantic Ocean : processes influencing deep and surface water distributions, Mar. Chem., 61, 55-68, 1998.

Statham, P. J. and Burton, J. D.: Dissolved manganese in the North Atlantic Ocean, 0-35 ${ }^{\circ}$ N, Earth Planet. Sci. Lett., 79, 55-65, 1986.

Thorpe, S. A. and White, M.: A deep intermediate nepheloid layer, Deep-Sea Res., 35, 1665-1671, 1988.

Van Aken, H. M.: The hydrography of the mid-latitude Northeast Atlantic Ocean II: The intermediate water masses, Deep-Sea Res. Part I, 47, 789-824, 2000.
Van Aken, H. M.: The hydrography of the mid-latitude Northeast Atlantic Ocean part III: The subducted thermocline water mass, Deep-Sea Res. Part I, 48, 237-267, 2001.

van der Zee, C, van Raaphorst, W., and Epping, E.: Absorbed Mn ${ }^{2+}$ and $\mathrm{Mn}$ redox cycling in Iberian continental margin sediments (northeast Atlantic Ocean), J. Mar. Res., 59, 133-166, 2001.

van der Zee, C, van Raaphorst, W., and Helder, W.: Fe redox cycling in Iberian continental margin sediments (NE Atlantic), J. Mar. Res., 60, 855-886, 2002.

Wells, M. L., Vallis, G. K., and Silver, E. A.: Tectonic processes in Papua New Guinea and past productivity in the eastern equatorial Pacific Ocean, Nature, 398, 601-604, 1999.

Witter, A. E., Lewis, B. L., and Luther III, G. W.: Iron speciation in the Arabian Sea, Deep-Sea Res. Part II, 47, 1517-1539, 2000.

Wollast, R. and Chou, L.: Ocean Margin EXchange in the Northern Gulf of Biscay: OMEX I. An introduction, Deep-Sea Res. Part II, 48, 14-15, 2971-2978, 2001.

Wu, J., Boyle, E., Sunda, W., and Wen, L.-S.: Soluble and colloidal iron in the oligotrophic North Atlantic and North Pacific, Science, 293, 847-849, 2001.

Wu, J. and Luther III, G. W.: Size-fractionated iron concentrations in the water column of the western North Atlantic Ocean, Limnol. Oceanogr., 39, 1119-1129, 1994.

Wu, J. and Luther III, G. W.: Spatial and temporal distribution of iron in the surface water of the northwestern Atlantic Ocean, Geochim. Cosmochim. Acta, 60, 2729-2741, 1996. 